\title{
Reassessing Nation-Branding: Danish Public Diplomacy towards Muslim-Majority Countries after the 2005 Cartoon Crisis
}

\author{
Radityo Dharmaputra \\ Departemen Hubungan Internasional Universitas Airlangga
}

\begin{abstract}
This article reassesses Danish efforts of nation-branding towards Muslimmajority countries after the 2005 Prophet Cartoon Crisis. It disputes Rasmussen \&Merkelsen's (2012) findings regarding the shifting Danish policy to a more brand-conscious policy. This article differentiates reactive crisis diplomacy and a brand-informed policy and finds that Danish policy towards Muslim-majority countries was closer to the principle of reactive crisis diplomacy, rather than a conscious nation-branding. Result from this research could be used as the basis for future research on the idea that nation branding could complement the use of classic diplomacy. As the Danish case has shown, the lack of coordination between governmental and non-governmental actors and the lack of conscious effort on nation branding could negate the possibility of creating a good brand image.
\end{abstract}

Keywords: Denmark, nation-branding, 2005 prophet cartoon crisis, public diplomacy

Artikel ini menakar kembali upaya Denmark dalam melakukan pencitraannegara (nation-branding) ke negara-negara mayoritas berpenduduk Muslim sesudah adanya krisis kartun Nabi tahun 2005. Artikel ini mempertanyakan temuan Rasmussen dan Mikkelsen (2012) mengenai pergeseran kebijakan Denmark menjadi kebijakan berbasis kesadaran pencitraan (brand). Dengan mendasarkan penelitian ini pada diskusi mengenai ambiguitas konseptual dari diplomasi public dan "nation-branding", artikel ini berargumen bahwa ada perbedaan antara diplomasi reaktif saat krisis dengan kebijakan sadarbrand. Artikel ini menemukan bahwa kebijakan Denmark lebih dekat dengan prinsip-prinsip diplomasi reaktif, daripada upaya pencitraan-negara. Temuan dari artikel ini bisa dijadikan dasar analisis mengenai kemungkinan pencitraan-negara menjadi pendukung upaya diplomasi klasik. Seperti yang nampak dari kasus Denmark, kurangnya koordinasi antara Negara dengan aktor non-negara dan kurangnya upaya sadar-pencitraan bias menegasikan kemungkinan positif penciptaan citra baik dari sebuah brand negara.

Kata Kunci: Denmark, pencitraan-negara, krisis kartun nabi 2005, diplomasi Publik. 
The year 2005 marked the beginning of a crisis in Danish relations with Muslim-majority countries. ${ }^{1}$ The Cartoon Crisis had started in 30 September after one of the Danish newspaper, Jyllands-Posten, published 12 cartoons of the Prophet Muhammad. The reactions, both from the local Muslim groups in Denmark and from Muslim-majority countries, were swift, ranging from local protests by Muslim groups in Denmark; united regional protests in the Middle East (Baroud 2006); the attack to several Danish embassies in Lebanon, Kenya, Bangladesh, and even Indonesia (The Guardian 2006); to the boycott of Danish products by some countries (Agra Europe 2006; NPR News 2006). ${ }^{2}$ The internationalization of the issue ${ }^{3}$ since 7 December 2005, when the Organization for Islamic Conference (OIC) discussed this issue and decided to complain to the United Nations, has generated what Prime Minister Anders Rasmussen considered as "the worst international crisis for Danish foreign policy since 1945” (quoted in Times Online 2006).

These varying kind of political responses from the Muslim groups in many countries triggered academic interests on this issue. Many scholars focused on the issue of the relations between Islam and the West, highlighting the potential clash of civilizations. For example, Douai (2007) tried to observe the differences on how the Arab mass media tried to portray the issue as part of the debate on the clash of civilization thesis. Müller and Özcan (2007) elaborated the cultural differences between the West and Islam in their political understanding of the cartoon. Interestingly, Powers (2008) argued that the Western media and analysts had been preoccupied with the civilizational narrative, which led to the inattention to the geopolitical realities of the issue. Other scholars (Andersen 2008; Gregersen 2009; Hansen 2006; Rostbøll 2010) focused on the philosophical debate about universal values and freedom of speech, and how these concepts were understood from the Western and Islamic perspectives. Others, such as Nielsen (2010) or Østergaard and Sinclair (2007) observed the issue of Danish Muslims and the way they integrated to the society. It seemed that many scholars were more interested in the cultural understanding of the issue, rather than the foreign policy implication.

\footnotetext{
${ }^{1}$ Instead of Islamic countries, this paper uses the term "Muslim-majority countries" to describe many countries which have a majority Muslim population (such as Turkey and Indonesia, but also many other countries such as Bangladesh and Lebanon) but ambiguous Islamic governance/government.

2 For timeline regarding the issue, Financial Times (2006) had provided a detailed timeline of events related to the cartoon crisis.

3 As termed and classified by Rynning \& Schmidt (2006). They classified the development of the issue into three categories: the $1^{\text {st }}$ phase (local conflict in Denmark); the $2^{\text {nd }}$ phase (the internationalization); and the $3^{\text {rd }}$ phase (the climax and crisis management). For different classification, see Lindekilde, Mouritsen, and ZapataBarrero (2009).
} 
Nonetheless, following PM Rasmussen's statement, some scholars also analysed the foreign policy aspects. Some focused on the security issues, by using the post-structuralist analysis and the theoretical framework of securitization to understand how the simple events such as cartoon drawing could initiate a security concern (Agius 2013; Hansen 2011a, 2011b). Others focused on how Danish government dealt with this issue, by using diplomacy as the focus of analysis (Arsenault \& Powers 2006; Lindholm \& Olsson 2011; Pultz 2012; Rolfe 2009). I follow the latter group in trying to elaborate the notion of Danish public diplomacy towards Muslim-majority countries. However, instead of focusing only on public diplomacy, I use the concept of branding, as developed by Anholt (2007). Following the conclusion from Rasmussen and Merkelsen (2012) that Danish efforts of public diplomacy towards the Muslim-majority countries had shifted to nation branding and the efforts of marketing the states, I try to reassess that conclusion by evaluating the Danish diplomatic efforts. I argue that Danish diplomatic efforts in branding themselves have followed the logic of reactionary policies during a crisis, and therefore have failed to brand themselves in most Muslim-majority countries. To build this argument, I start this paper by discussing the theory of public diplomacy and nation-branding before analysing Danish policy after the 2005 Cartoon Crisis.

\section{Public Diplomacy and Branding: A Conceptual Review}

According to Rasmussen and Merkelsen (2012), Danish diplomacy regarding the cartoon crisis suffered because the government put reputation, marketing, and nation branding at the expense of public diplomacy and security policy. To assess this remark, some understanding of the relation between the concept of branding and public diplomacy must be developed.

As Anholt (2003) argued, public diplomacy is part of the nation brand, aside from exports, tourism, and investment. However, as Zaharna (2009) argued, both concepts are related to the process of constructing and dissemination information to targeted audiences, in which the goal is to differentiate the entity in the minds of the audiences. One could argue that the main goal of public diplomacy and branding is the same, which is to spread information about the said entity. In doing so, the differences between public diplomacy and branding is not that immense. Using the logic from Anholt (2007), public diplomacy could be mixed with brand management, therefore creating the new terminology, "competitive identity".

Nonetheless, the term "public diplomacy" in its current meaning dated back to 1965, when Edmund Gullion stated this new diplomacy between 
private groups in one country and another, and the influence of public attitude to the management of foreign policy, as part of public diplomacy (Cull 2009). In this understanding, the cartoon crisis had forced some changes in government's foreign policy, thereby making it a case of public diplomacy. As Kelley (2009) argued, the damage to a country's image could prompt that country to undergo an effort of reactive public diplomacy. Kelley $(2009,78)$ argued that this kind of reactive diplomacy (as opposed to the proactive, long-term public diplomacy) intends to control the damage and guarantee the minimal impact to the prior relationship. As many scholars 4 have argued, in this kind of understanding, the policies of Danish government during the cartoon crisis could be described as crisis diplomacy. Nonetheless, if this is the case, then why the latest analysis by Rasmussen and Merkelsen argued about the tendency to focus only on the reputation and branding, instead of diplomacy? To understand this confusion, we have to delve into the concept of branding.

In recent years, the literatures on branding have been developing, especially with regard to the concept of nation branding. As Van Ham (2001) said, the year of traditional diplomacy has gone, replaced by the importance of the brand of the states in order to compete against each other. Being coined in 1996 by Simon Anholt, the term "nation branding" borrowed the idea of branding from marketing studies, which describes the process of designing, planning, and communicating the name and identity to build or manage the reputation of the nation (Anholt 2007, 4). It is interesting to note that Anholt (2007, 5) argued that nation could not be branded like products or companies. Instead of branding a nation, he suggested that nation's reputation in the world was constructed from six different sources, which he then termed as the "hexagon of competitive identity". One of the sources, which would relate to the case of Danish cartoon crisis, is the policies of the government, consist of both the foreign and domestic policies reported in the international media (Anholt 2007, 25). Therefore, according to Anholt $(2007,49)$, any kind of negative experience (whether it was real or perceived), such as attack to individual, values, religion, or population, could damage the whole reputation of a country.

Following this logic, as Anholt (2007) also argued when describing the declining position of Denmark in Nation Brands Index (NBI), the cartoon crisis has surely damaged Denmark's reputation. The problem then, how has the country reacted? This was where the problem started, according to Rasmussen and Merkelsen (2012). In their view, Danish government focused only on rebuilding their reputation (as measured by the NBI) rather than addressing the real security issues related to the

4 For example, Lindholm \& Olsson (2011) or Pultz (2012). 
cartoon crisis. On the contrary, I argue that if Denmark's policy tends to focus on their reputation in the world, then it is logical that during and after the crisis, they will try to manage and rebuild their brand reputation. However, if their position followed a pragmatic notion, then the response to the crisis might reflected that pragmatism, instead of a coordinated reputation branding.

Regarding Rasmussen and Merkelsen's argument about the differentiation between nation branding and public diplomacy, I argue that the way their responseswere constructed is the crucial factor. Following Zaharna's argument, both nation branding and public diplomacy are targeted to create an image and disseminating that image to the audience. Following Anholt (2007), a successful brand-informed policy would create a coordinated action of all stakeholders (not just government), and the policies were aligned to the national policy (instead of a reactionary policies). In this instance, the differences between a reactive, crisis public diplomacy and the brand-informed policy is obvious. Therefore, in the next section,I evaluate the differences between the initial Danish policies towards Muslim-majority countries and the response to the crisis, and the distinction between pragmatic crisis response and the long-term views of branding.

\section{Denmark's Diplomacy towards Muslim Countries}

In terms of governmental relations with the Muslim-majority countries, Denmark had quite a normal relation with almost all countries. In line with their so-called "Nordic Exceptionalism" (Browning 2007), which contained the notions of peacekeepers, bridge builders, solidarity with the Third World countries, and their system of social democracy, Denmark had promoted several projects to the Muslim-majority countries. For example, to demonstrate their solidarity to the Third World, since 2003 the Danish government had created the Danish-Arab Partnership Programme (DAPP) which focused on reform and democratization in the Middle East and North African (MENA) region. It was part of the Danish International Development Agency (DANIDA) initiatives to the Arab world.

However, the major focus of DANIDA was not the Arab countries as such, but the poor countries in Africa. Of course, some countries such as Kenya 5 , India ${ }^{6}$, and Pakistan7, were the initial eight priority countries of

\footnotetext{
5 Where some attacks to the embassies happened on 10 February 2006 (Financial Times, 21 March 2006).

${ }^{6}$ Where some clashes between Muslim protesters and police happened on 17 February 2006 (Financial Times, 21 March 2006).
} 
Denmark's official development assistance (ODA) in 1968 (Denmark Ministry of Foreign Affairs 2012). In 1975, India, Bangladesh ${ }^{8}$, and Kenya became the main four recipient countries, along with Tanzania. It highlighted the principle of Danish solidarity with the Third World, albeit not saying much about the Muslim-majority countries.

Denmark's relations with Turkey and Indonesia, two of the biggest Muslim-majority countries, was normal before 2005. To be more precise, the relations were nothing special, due to the geographical distance between Indonesia and Denmark, for example. Nevertheless, since 1968 and especially after 2000, Denmark had given ODA to Indonesia (Denmark Ministry of Foreign Affairs 2012). In the Middle East, Denmark started giving ODA to Egypt since 1969, to Yemen since 1973, to Iraq between 1975-1980 and after 2003, and to the Palestinian Authority since 1994 (Denmark Ministry of Foreign Affairs 2012). It is sufficed to say that before 2005, Denmark's reputation as a donor was quite respectable.

However, two events preceded the changing situation in the 2005-2006 cartoon crisis. The first was the election of conservative government led by Rasmussen in 2001. As Holm (2006) observed, the new government changed the immigration discourses, making it tougher for the Muslim immigrants due to the narratives of the "fifth column" and "Trojan horses" used by the extreme Right parties. Their main narrative was that the problem of identities, especially when the numbers of Muslim immigrants at that time was compared to the population of Denmark, posed as a threat to the basic identity notion that Denmark is a monocultural and homogenous country in which its values was based on (Holm 2006).

This problem was echoed in the foreign policy context after 2001. As Lawler (2007) argued, Danish refugee policy after 2001 received heavy criticism from the other Nordic countries (particularly Sweden) and the UN High Commissioner for Refugees. Denmark's decision to join the war in Afghanistan and Iraq had prompted Rynning (2003) to call Denmark as "shifting from civilian actor to strategic actor", despite the fact that Denmark had also joined the 1991 Gulf War (Holm 2006). As Browning (2007) said, it represented "the Clausewitzian shift" from Denmark, elucidated by their decision to start using military forces as international political tool. It was clear from these conflicting facts, of development assistance and Nordic identity on the one hand, and the military forces with good relations with the US on the other hand, that

\footnotetext{
7 Where some attacks, protests, and recalling of Danish ambassador happened during February 2006 (Financial Times, 21 March 2006).

${ }^{8}$ Another place with the clashes between police and protesters regarding the cartoon (Financial Times, 21 March 2006).
} 
Danish policies are more pragmatic compared to its propagated Nordic identities. Even though the Nordic solidarism was still used as one of the image, the security pragmatism still triumphed. Denmark was more concerned with the strategic aspects of their policies rather than its reputation and its Nordic brand. In the words of Lawler (2007), Denmark, especially with their Arab Initiatives from 2003, was seen as merging more towards the mainstream Western muscular liberal internationalism, instead of their so-called Nordic exceptionalism.

These conditions were, at first, unnoticed by the Muslim world. Only after the 2005 cartoon crisis that they began to notice that Denmark was, together with the US, having an illegitimate military presence in the Muslim-majority countries (Baroud 2006). The attacks on several embassies in Arab countries, Iran, and Indonesia, had forced the government to withdraw several ambassadors and diplomatic envoys in those countries. The boycott to Danish products had forced some companies to respond in their own way, highlighting the lack of coordinated brand-informed policies in Denmark.

The initial response from the Danish government was to explain that the cartoon was about freedom of speech and that the government could not intervene. As Holm (2006) argued, the insistence to focus on the issue of the freedom of speech was an interesting one. On the one hand, it could be used as the proof that Danish brand identity was the promotion of free speech. Their insistent effort was highlighted by the PM's assertion that the crisis "had taught him not to compromise on the principle of freedom of expression and free press" (Rasmussen 2015). It would also connect to the notion of democracy in their 2003 Arab Partnership.

However, this response was dissimilar to the response from corporations such as Arla Foods, the one corporation that suffered from the boycott. As Knudsen et al. $(2008,22)$ argued, Arla, suffered $\$ 85$ million due to the boycott, decided to distance themselves from the cartoons by claiming their disagreement with the reason of its publications. It was logical that corporation reacted in that manner, but the main point is the divergence between government and corporation. If Denmark was focused on rebuilding reputation (as argued by Rasmussen and Merkelsen 2012), the coordination between government and nongovernmental actors should be perceptible. Taking into consideration the comment from Arla Managing Director PederTuborgh in 2006, that "the Danish government should have intervened by entering a dialogue with Muslim communities", and that these suggestions was neglected (Knudsen et al. 2008), the insufficient coordination between the stakeholders was palpable. 
Nevertheless, the government have performed some public diplomacy efforts. One effort was the "Dialog Ambassadors" project funded by the Ministry of Foreign Affairs under the framework of the DAPP. It was conducted in 2009 by the Danish Youth Council (DYC) with the cooperation from NGOs in Egypt and Jordan. As Pultz (2012) argued, even though there were some changes in the participant's perception due to the process of dialogue, some problems remained. For example, the chosen ambassadors were the young activists, which might not represent their society. Furthermore, the efforts at the societal level could not change the nation's brand image, because the coordination of all stakeholders especially at the governmental level was needed. In this effort to fund the NGOs after the crisis, the government acted precisely in line with Kelley's argument about crisis public diplomacy, to limit the magnitude of the damage.

Lindholm and Olsson (2011) observed other efforts by the government related to the communication strategies that were used. They found that, consistent with the initial position, the government had insisted to frame the issue as the "freedom of speech. Even though this strategy had managed to convince the domestic audiences, but it failed to generate similar responses from the external audiences, namely the Muslimmajority countries. As Holm (2006) put it nicely, the Danish nation had failed to recognize the fact that others do not consider Danish policies as the good policies. Their efforts to alienate the Muslim community in Denmark had triggered inefficiency to their later efforts in communicating directly with the Muslim communities using Arablanguage channel (Lindholm\& Olsson 2011). Furthermore, these efforts mirrored the pragmatic logic of Danish foreign policies. Instead of coordinated responses, the research by Lindholm\& Olsson (2011) shown that the government tried to reframe this issue several times, but failed to do that due to the initial insistence to the "freedom of speech" narrative.

An interesting insight that proved this persistence to the notion of "freedom of speech", could be seen in Andreasen's view (2008). A former Danish high-ranking diplomat, his view regarding the events could be considered as the representation of the pragmatic thinking. The way he praised Danish government transparency and persistence was quite amusing. His view about how these stances had gained Denmark more friends among "normal" people could be considered in line with the previous accusation of Denmark offending Muslims. Furthermore, he based his arguments on the NBI data, which showed that the only place where Denmark's reputation has dwindled was in the Muslimmajority countries. He even argued that counting only the moderate countries such as Indonesia and Turkey, Denmark's reputation was growing. 
These kind of positions was typical of the government's response to the crisis, and as Lindholm and Olsson (2011) argued, only after the crisis deepened and entered the escalation phases that the government tried to change their position, but not enough to reverse their initial stance. This was a symptom of a crisis response, without even trying to rebuild their reputation.

\section{Concluding Remarks: A Failed Branding?}

The case of Danish responses and their diplomacy towards the Muslimmajority countries could not be considered as the tendency to focus on nation branding and neglect the diplomatic aspects of the crisis, as Rasmussen and Merkelsen (2012) argued. The first reason is that Denmark's initial position has been shifting to a pragmatic-militaristic aspect. Following Browning (2007), I argue that Danish "Nordic exceptionalism" had long gone, replaced by Danish "Clausewitzian exceptionalism", common in the mainstream Western states such as the US. Instead of a long-term branding and continuous public diplomacy towards the Muslim-majority countries, Denmark had been using their initiatives such as the DAPP to build more muscular foreign policy towards the Arab states. Of course, we could consider the possibility that the muscular foreign policy was the brand that Denmark tries to pursue. However, their response towards the cartoon crisis and their subsequent public diplomacy efforts contradicted that argument.

Their insistent initial response, continuing to a series of efforts to reframe the issue but insisting on staying at the same stance, was typical of a response towards a crisis without any long-term brand-informed policies. Instead of rebuilding their brand so they could be accepted in the Muslim-majority countries, as many Danish corporations would do, the government had chosen to alienate the Muslim-majority countries and might have alienated the Muslim groups in Denmark as well. As Hill $(2013,81)$ stated, this crisis has left a deep division in Danish society for the years to come. Furthermore, as Rasmussen and Merkelsen (2012) pointed out, even though the Danish government spent much money (around \$77.5 million) for the "Branding Denmark Task Force" since 2007 with the vision of increasing their position in the NBI list, the result was a positional stagnancy. I argue that, based on evaluating Danish clumsy efforts at crisis diplomacy, and their non-coordinated (and probably non-existence) branding policy related to the cartoon crisis, their positional stagnancy in the NBI list was relatedto their inability in conducting a brand-informed policy. Therefore, I conclude that the recurring pattern of Danish foreign policy during and after the 2005 Cartoon Crisis are the lack of proactive diplomacy (choosing 
instead to have a reactive crisis diplomacy without any long-term vision) and the lack of conscious nation branding in the Muslim-majority countries.

This paper was not intended to explain the causes of the failure of Danish policy. However, I would argue that Holm's argument about the discrepancies between conflicting discourses of identity in the local level could be the answer. After all, one of the sources of brand image was local policies and national self-image. It was possible that these unfinished local debates were the reason behind the continuous problem between Muslim groups and Danish society to the extent that it could influence the foreign policy and local reception of the future Muslim immigrant.

\section{Bibliographies}

\section{Books \& Book Chapter}

Anholt, S., 2003. Brand New Justice: The Upside of Global Branding. Oxford: Butterworth-Heinemann. ,2007. Competitive identity. The new brand management for nations, cities and regions. New York: Palgrave Macmillan.

Cull, N. J., 2009. "Public Diplomacy before Gullion: The Evolution of a Phrase", in Snow, N \& Taylor, P. M. (eds.), 2009. Routledge Handbook of Public Diplomacy. New York, NY: Routledge.

Hill, C., 2013.The National Interest in Question: Foreign Policy in Multicultural Societies. Oxford, UK: Oxford University Press.

Kelley, J. R., 2009. "Between 'Take-Offs' and 'Crash Landings': Situational Aspects of Public Diplomacy", in Snow, N \& Taylor, P. M. (eds.), 2009. Routledge Handbook of Public Diplomacy. New York, NY: Routledge.

Rynning, S., 2003. "Denmark as a Strategic Actor? Danish Security Policy after 11 September", in Carlsen, P.\&Mouritzen, H. (eds.), 2003.Danish Foreign Policy Yearbook 2003. Copenhagen: Danish Institute for International Affairs.

Zaharna, R. S., 2009. "Mapping out a Spectrum of Public Diplomacy Initiatives: Informational and Relational Communication Frameworks", in Snow, N \& Taylor, P. M. (eds.), 2009. Routledge Handbook of Public Diplomacy. New York, NY: Routledge. 


\section{Official Publications}

Danida: 5o Years, 2012. Copenhagen: Danida, Ministry of Foreign Affairs of Denmark.

\section{Reports \& Policy Briefs}

Agra Europe, 2006. "Cartoon row hits Danish poultry exports",Agra Europe 2195, 17 February 2006.

Andersen, L. E., 2008. "Freedom of Speech, Battle over Values, and the Political Symbolism of the Muhammad Drawings", DIIS Report, Number 6.

Arsenault, A. \& Powers, S., 2006. "The Danish Cartoon Crisis: The Import and Impact of Public Diplomacy", USC of Public Diplomacy Special Reports, 5 April.

Holm, U., 2006. "Denmark: The Ugly Duckling in International Politics?", DIIS Policy Brief, Number ARI 19/2006, 22 February.

Rynning, S. \&Schmidt, C. H., 2006. "Muhammad Cartoons in Denmark: From Freedom of Speech to Denmark's Biggest International Crisis Since 1945”, UNISCI Discussion Papers, Number 11, May.

\section{Journal Articles}

Agius, C., 2013. "Performing identity: The Danish cartoon crisis and discourses of identity and security", Security Dialogue, 44 (3): 241258.

Andreasen, U., 2008. "Reflections on Public Diplomacy after the Danish Cartoon Crises: From Crisis Management to Normal Public Diplomacy Work", The Hague Journal of Diplomacy, 3 (2): 201207.

Browning, C. S., 2007. "Branding Nordicity: Models, Identity and the Decline of Exceptionalism", Cooperation and Conflict, 42 (1): 27-51.

Douai, A., 2007. "Tales of Transgression or Clashing Paradigms: The Danish Cartoon Controversy and Arab Media", Global Media Journal, 6 (10): 1-13.

Gregersen, N. H., 2009. "On Taboos: The Danish Cartoon Crisis 20052008”, Dialog: A Journal of Theology, 48 (1): 79-96.

Hansen, L., 2011a. "The politics of securitization and the Muhammad cartoon crisis: A post-structuralist perspective", Security Dialogue, 43 (4-5): 357-369.

, 2011b. "Theorizing the image for Security Studies: Visual securitization and the Muhammad Cartoon Crisis", European Journal of International Relations, 17 (1): 51-74. 
Hansen, R., 2006. "The Danish Cartoon Controversy: A Defence of Liberal Freedom", EUSA Review, 19 (2): 1-6.

Knudsen, K., Aggarwal, P., \&Maamoun, A., 2008. "The Burden of Identity: Responding to Product Boycotts in the Middle East", Journal of Business \& Economics Research, 6 (11): 17-26.

Lawler, P., 2007. "Janus-Faced Solidarity: Danish Internationalism Reconsidered", Cooperation and Conflict, 42 (1): 101-126.

Lindekilde, L., Mouritsen, P., \& Zapata-Barrero, R., 2009. "The Muhammad cartoons controversy in comparative perspective", Ethnicities, 9 (3) 291-313.

Lindholm, K. \& Olsson, E., 2011. "Crisis Communication as a Multilevel Game: The Muhammad Cartoons from a Crisis Diplomacy Perspective”, International Journal of Press/Politics, 16 (2): 254271.

Müller, M. G. \&Özcan, E., 2007. "The Political Iconography of Muhammad Cartoons: Understanding Cultural Conflict and Political Action”, PS: Political Science \& Politics, 40 (2): 287-291.

Nielsen, J. S., 2010. "Danish Cartoons and Christian-Muslim Relations in Denmark", Exchange, 39 (3): 217-235.

Østergaard, K. \& Sinclair, K., 2007. "Danish Muslims, the Cartoon Controversy, and the Concept of Integration", Global Dialogue, 9 (3-4): 65-74.

Powers, S., 2008. "Examining the Danish cartoon affair: mediatized cross-cultural tensions?”, Media, War \& Conflict, 1 (3): 339-359.

Pultz, K., 2012. "Dialogue and Power: Understanding Danish Public Diplomacy Efforts in the Middle East", The Hague Journal of Diplomacy, 7 (2): 161-180.

Rasmussen, R. K. \&Merkelsen, H., 2012. "The new PR of states: How nation branding practices affect the security function of public diplomacy", Public Relations Review, 38 (5): 810-818.

Rolfe, M., 2009. "Clashing Taboos: Danish Cartoons, the Life of Brian and Public Diplomacy", The Hague Journal of Diplomacy, 4 (3): 261-281.

Rostbøll, C. F., 2010. "The Use and Abuse of 'Universal Values' in the Danish Cartoon Controversy", European Political Science Review, 2 (3): 401-422.

Van Ham, P., 2001. "The Rise of the Brand State", Foreign Affairs, 80 (5), September/October.

\section{Online Articles}

Baroud, R., 2006. "Punishing Denmark, the wrong enemy"[online].inhttp://www.atimes.com/atimes/Middle_East/HB 02Ak02.html [accessed 3 January 2016]. 
Financial Times, 2006. "Timeline: How the cartoon crisis unfolded" [online].inhttp://www.ft.com/cms/s/2/d3oboc22-96ee-11da-82b70000779e2340.html\#axzz3OG6ux286 [accessed 3 January 2016].

NPR News, 2006. "Cartoon Controversy Slams Denmark's Economy" [online].

http://www.npr.org/templates/story/story.php?storyId=5199960 [accessed 7 January 2016].

Rasmussen, A. F., 2015. "Interview with Anders Fogh Rasmussen: Muhammad Cartoons Taught Us Not To Compromise Freedom" [online].inhttp://bigthink.com/videos/why-denmark-stood-bymohammed-depictions-with-anders-fogh-rasmussen [accessed 10 January 2016].

The Guardian, 2006. "Danes told to leave Indonesia after terrorist threat reported"

[online].inhttp://www.theguardian.com/world/2006/feb/13/indon esia.muhammadcartoons [accessed 5 January 2016].

Times Online, 2006. "70,000 gather for violent Pakistan cartoons protest"

[online].inhttp://www.thetimes.co.uk/tto/news/world/asia/article2 612186.ece [accessed 6 January 2016]. 